\title{
Incidence and Distribution of Important Viral Pathogens in Some Iranian Potato Fields
}

R. Pourrahim and Sh. Farzadfar, Department of Plant Virology, Plant Pests and Diseases Research Institute, P.O. Box 19395-1454, Tehran, Iran; A. R. Golnaraghi, Department of Plant Protection, College of Agriculture and Natural Resources, Science and Research Campus, Islamic Azad University, P.O. Box 14515-775, Tehran, Iran; and A. Ahoonmanesh, Department of Plant Pathology, College of Agriculture, Esfahan University of Technology, Esfahan, Iran

\begin{abstract}
Pourrahim, R., Farzadfar, Sh., Golnaraghi, A. R., and Ahoonmanesh, A. 2007. Incidence and distribution of important viral pathogens in some Iranian potato fields. Plant Dis. 91:609-615.

From a total of 8,135 potato leaves collected from 132 fields in 11 provinces of Iran, the incidence and distribution of Alfalfa mosaic virus (AlMV), Eggplant mottled dwarf virus (EMDV), Potato leafroll virus (PLRV), Potato virus A (PVA), Potato virus M (PVM), Potato virus $S$ (PVS), Potato virus $X$ (PVX), Potato virus $Y$ (PVY), and Tomato yellow fruit ring virus (TYFRV) were assessed using serological and biological methods. Based on enzyme-linked immunosorbent assay (ELISA) results, viruses in decreasing order of incidence in potato were PVS (35.9\%), PVY (34.4\%), PVA (27.0\%), PVX (20.8\%), PLRV (13.9\%), PVM (9.0\%), AlMV (7.0\%), TYFRV (5.9\%), and EMDV (5.1\%). All 132 fields surveyed had some degree of virus infection, ranging from 28.8 to $98.6 \%$, with an overall incidence of $75.2 \%$. The highest and lowest incidence of virus infections among the surveyed provinces occurred in Kerman (93.2\%) and Ardabil (56.7\%), respectively. Overall, 25.0 and 50.2\% of the collected potato samples had single or mixed infections, respectively. High levels of mixed infections were found between PVX and PVS (8.6\%), and PVX and PVY (7.6\%). Moreover, co-infection of samples with PVS and PVY, PVA and PVS, and PVA and PVY, the aphid-vectored virus/virus combinations, occurred at the highest incidence in almost all provinces surveyed, 15.3, 13.8, and 12.8\%, respectively. In this study, Beet curly top virus was detected in symptomatic potato samples collected from some fields in the Kermanshah province.
\end{abstract}

Additional keywords: aphid population, host range, insect fauna

Potato is an important field crop which is cultivated widely throughout the world. Iran is the fifth largest potato producer in Asia, producing 3.6 million tonnes annually (22). Iran has four main distinct potato growing regions, namely the northwest (including Ardabil, Azarbayejan-e-gharbi, Azarbayejan-e-sharqi, Hamedan, and Zanjan provinces), northeast (Khorasan), central provinces (Chaharmahal-va-bakhtiyari, Esfahan, Fars, and Tehran), and southern provinces (concentrated in and adjacent to Kerman and Hormozgan). Except for the southern region, nearly the entire crop is planted in spring during May and June and harvested from September to October. In the southern production region, potato is cultivated from December through February. According to the Food and Agriculture Organization (FAO) production statistics, the area covered by potato in Iran increased from 168,862 ha in 2000 to

Corresponding author: R. Pourrahim

E-mail: pourrahim@yahoo.com

Accepted for publication 24 October 2006.

doi:10.1094/PDIS-91-5-0609

(C) 2007 The American Phytopathological Society
190,000 ha in 2004 , with $3,658,035$ and $4,180,000$ tonnes of production, respectively $(21,22)$.

Among the factors limiting potato production in the world, viral diseases appear to play a significant role (29). For example, losses of tuber yield ranging from 10 to $80 \%$ for Potato virus $Y$ (PVY) (16), $10 \%$ for Potato virus $X$ (PVX) (39), and 33 to $55 \%$ for Potato leafroll virus (PLRV) (38) have been reported. Moreover, viral diseases cause greater economic losses in potato production if plants are infected at early growth stages or with mixed infections (40). Typical viral disease symptoms in leaves include mosaic, mottling, leaf roll, necrosis, rugosity, crinkling, and leaf drop, as well as streak and necrosis symptoms on stems (29). However, some viruses like Potato virus $M$ (PVM) infect many potato cultivars asymptomatically and induce very mild symptoms in other cultivars (9), making visual assessment of virus infections difficult. Of about 37 different viruses naturally infecting cultivated potatoes worldwide $(32,49)$, Alfalfa mosaic virus (AlMV), Eggplant mottled dwarf virus (EMDV), PLRV, Potato virus $A$ (PVA), PVM, Potato virus S (PVS), PVX, and PVY are known to occur in fieldgrown potatoes in Iran $(14,15,25,36,37,41$,
45,47). Tomato yellow fruit ring virus (TYFRV) infection of potatoes was first reported in 2001, and the causal agent was originally identified as Tomato spotted wilt virus (TSWV) (46). The aforementioned viruses are naturally transmitted through infected seed tubers and, except for PVX, EMDV, and TYFRV, by aphid vectors as well $(6,29)$.

Despite the economic importance of potato in Iran, only limited records and local information are available on the incidence of viral diseases and their impact on production. In recent years, there has been increased concern about virus infections in potato crops in Iran. Potato yields (about $19 \mathrm{t} / \mathrm{h}$ ) are consistently low compared with other Asian countries such as Japan (31 $\mathrm{t} / \mathrm{h})$ and Turkey (23 t/h) (40). In this study, surveys were carried out during the growing season in 2003, encompassing 11 provinces of Iran to estimate the incidence of potato virus diseases and their potential importance. This was the first major survey on the occurrence, distribution, and incidence of potato viruses in the main potato producing areas of Iran. The information obtained will be a key element in future research to develop improved control strategies for potato virus diseases in Iran.

\section{MATERIALS AND METHODS}

Plant sampling. Surveys were conducted in 11 widely separated potato production provinces of Iran during the summer of 2003, in a period from August to September. Overall, 132 fields were surveyed and 8,135 leaf samples were collected before or through the flowering stage, 50 to 90 days after planting (Table 1, Fig. 1). In each province, fields were randomly selected using a predetermined distance criterion, with the distance between fields ranging from 5 to $20 \mathrm{~km}$. Samples from separate plants (50 to 80 per field) were collected without regard to symptoms, and were collected along the field diagonals such that at least 15 plants per hectare were collected. A total of 47 leaf samples from plants showing Beet curly top virus-like symptoms were also collected from three fields in Kermanshah province (Fig. 1). These symptoms included pinched and retarded leaf growth, cupped leaflets, and chlorosis. Samples 
consisted of two or three potato leaves taken from the shoot apex. Each plant sample was placed in a separate plastic bag, transported immediately on ice, and stored at $4^{\circ} \mathrm{C}$ until tested by enzyme-linked immunosorbent assay (ELISA). Virus disease incidence in each field was expressed as the percentage of virus positive leaves relative to the total number of plants tested. Disease incidence was also estimated based on symptoms recorded for the samples collected from each field surveyed as described above.

Sources of antibodies and positive samples. Commercial ELISA kits against PLRV, PVA, PVM, PVS, PVX, and PVY were purchased from Bioreba (Reinach, Switzerland), and AlMV from Sanofi Phyto-Diagnostics (Libourne, France). The ELISA for TYFRV detection (As-0526), a recently proposed species in the genus Tospovirus $(54,55)$, was kindly provided by S. Winter (DSMZ, Braunschweig,
Germany). IgGs and alkaline phosphataseconjugated IgGs were used at the dilutions recommended by the manufacturers. EMDV IgGs were produced against an Iranian isolate of EMDV from potato (25). Beet curly top virus (BCTV) antibodies were kindly provided by M. Bahar (College of Agriculture, Esfahan University of Technology, Esfahan, Iran), and an infected sugar beet sample was used as the positive control (24).

Serological assays. The double antibody sandwich ELISA (DAS-ELISA) procedure was performed according to the general protocol described by Clark and Adams (13). ELISA plates (Nunc Maxisorb, Denmark) were coated with $100 \mu \mathrm{l}$ of the recommended dilution of $\mathrm{IgG}$ in carbonate coating buffer $\left(15 \mathrm{mM} \mathrm{Na} \mathrm{CO}_{3}\right.$, $35 \mathrm{mM} \mathrm{NaHCO}_{3}$, and $5 \mathrm{mM} \mathrm{NaN}_{3}, \mathrm{pH}$ 9.6) and incubated overnight at $4^{\circ} \mathrm{C}$. Samples were extracted (1:5 wt/vol) in phosphate buffered saline (PBS) $(2.7 \mathrm{mM} \mathrm{KCl}, 5 \mathrm{mM}$
$\mathrm{NaN}_{3}, 8 \mathrm{mM} \mathrm{Na}_{2} \mathrm{HPO}_{4}, 1 \mathrm{mM} \mathrm{NaH} \mathrm{PO}_{4}$ and $0.13 \mathrm{M} \mathrm{NaCl}$ ) containing $2 \%$ polyvinylpyrrolidone (PVP)-24,000 and $0.05 \%$ Tween 20, pH 7.4. Plates were washed four times at 5-min intervals with washing buffer (PBS containing 0.05\% Tween 20), and $100 \mu \mathrm{l}$ of plant extract was added to each well and incubated overnight at $4^{\circ} \mathrm{C}$. After washing the plates, $100 \mu \mathrm{l}$ of alkaline phosphatase-conjugated $\mathrm{IgG}$ diluted in conjugate buffer (PBS, pH 7.4, containing $2 \%$ PVP-24,000, $0.05 \%$ Tween 20, 0.2\% bovine serum albumin, and $1 \mathrm{mM} \mathrm{MgCl}_{2}$ ) was added and incubated $3 \mathrm{~h}$ at $37^{\circ} \mathrm{C}$. Wells were washed and incubated with 100 $\mu \mathrm{l}$ of substrate $(9.7 \%$ diethanolamine, $\mathrm{pH}$ 9.8 , containing $1 \mathrm{mg} / \mathrm{ml}$ of $p$-nitrophenyl phosphate and $5 \mathrm{mM} \mathrm{NaN}$ ) for $1 \mathrm{~h}$ at room temperature, and the absorbance was determined at $405 \mathrm{~nm}$ using an ELISAreader (Multiscan-334, Labsystems, Finland). A sample was considered positive (infected) if the absorbance at $405 \mathrm{~nm}$

Table 1. Laboratory test results of potato leaf samples collected from 132 fields in different provinces of Iran in the year $2003^{\mathrm{a}}$

\begin{tabular}{|c|c|c|c|c|c|c|c|c|c|c|c|}
\hline \multirow[b]{2}{*}{ Province } & \multirow{2}{*}{$\begin{array}{l}\text { No. of } \\
\text { fields }\end{array}$} & \multirow{2}{*}{$\begin{array}{l}\text { No. of } \\
\text { samples }\end{array}$} & \multicolumn{9}{|c|}{ Viruses $^{\mathbf{b}}$} \\
\hline & & & AIMV & PLRV & PVA & PVM & PVS & PVY & PVX & TYFRV & EMDV \\
\hline Ardabil & 14 & 884 & $\begin{array}{c}22(2.5)^{\mathrm{c}} \\
0.0-5.0^{\mathrm{d}} \\
(13)^{\mathrm{e}}\end{array}$ & $\begin{array}{c}40(4.5) \\
1.6-8.8 \\
(14)\end{array}$ & $\begin{array}{c}149(16.9) \\
6.1-28.6 \\
(14)\end{array}$ & $\begin{array}{c}25(2.8) \\
0.0-5.7 \\
(11)\end{array}$ & $\begin{array}{c}184(\mathbf{2 0 . 8}) \\
6.1-32.9 \\
(14)\end{array}$ & $\begin{array}{c}140(15.8) \\
4.5-23.0 \\
(14)\end{array}$ & $\begin{array}{c}116(13.1) \\
3.0-20.0 \\
(14)\end{array}$ & $(0.0)$ & $\begin{array}{c}4(0.5) \\
0.0-1.9 \\
(4)\end{array}$ \\
\hline $\begin{array}{l}\text { Azarbayejan-e- } \\
\text { sharqi }\end{array}$ & 12 & 687 & $\begin{array}{c}47(6.8) \\
0.0-11.4 \\
(10)\end{array}$ & $\begin{array}{c}53(7.7) \\
0.0-14.9 \\
(10)\end{array}$ & $\begin{array}{c}84(12.2) \\
6.4-24.3 \\
(12)\end{array}$ & $\begin{array}{c}56(8.2) \\
0.0-18.6 \\
(11)\end{array}$ & $\begin{array}{c}196(\mathbf{2 8 . 5}) \\
13.3-43.9 \\
\quad(12)\end{array}$ & $\begin{array}{c}93(13.5) \\
6.0-22.6 \\
(12)\end{array}$ & $\begin{array}{c}123(17.9) \\
5.1-28.6 \\
(12)\end{array}$ & $\begin{array}{c}8(1.2) \\
0.0-3.0 \\
(5)\end{array}$ & $\begin{array}{c}5(0.7) \\
0.0-3.8 \\
(4)\end{array}$ \\
\hline $\begin{array}{l}\text { Chaharmahal-va- } \\
\text { bakhtiyari }\end{array}$ & 12 & 734 & $\begin{array}{c}49(6.7) \\
0.0-11.1 \\
(10)\end{array}$ & $\begin{array}{c}110(15.0) \\
0.0-27.6 \\
(11)\end{array}$ & $\begin{array}{c}214(29.2) \\
8.2-42.5 \\
(12)\end{array}$ & $\begin{array}{c}106(14.4) \\
0.0-31.5 \\
(10)\end{array}$ & $\begin{array}{c}264(\mathbf{3 6 . 0}) \\
10.2-61.8 \\
\quad(12)\end{array}$ & $\begin{array}{c}258(35.1) \\
16.0-47.9 \\
\quad(12)\end{array}$ & $\begin{array}{c}203(27.7) \\
8.6-39.5 \\
(12)\end{array}$ & $\begin{array}{c}16(2.2) \\
0.0-5.6 \\
(8)\end{array}$ & $\begin{array}{c}112(15.3) \\
3.3-31.5 \\
(12)\end{array}$ \\
\hline Esfahan & 13 & 813 & $\begin{array}{c}78(9.6) \\
3.3-17.9 \\
(13)\end{array}$ & $\begin{array}{c}186(22.9) \\
14.5-33.9 \\
(13)\end{array}$ & $\begin{array}{c}192(23.6) \\
13.0-38.9 \\
(13)\end{array}$ & $\begin{array}{c}59(7.3) \\
0.0-17.2 \\
(11)\end{array}$ & $\begin{array}{c}321(\mathbf{3 9 . 5}) \\
25.0-53.0 \\
(13)\end{array}$ & $\begin{array}{c}264(30.3) \\
11.1-48.3 \\
\quad(13)\end{array}$ & $\begin{array}{c}173(21.3) \\
7.5-35.9 \\
(13)\end{array}$ & $\begin{array}{c}10(1.2) \\
0.0-4.6 \\
(6)\end{array}$ & $\begin{array}{c}56(6.9) \\
0.0-17.2 \\
(11)\end{array}$ \\
\hline Hamedan & 12 & 779 & $\begin{array}{c}114(14.6) \\
7.9-20.9 \\
(12)\end{array}$ & $\begin{array}{c}34(4.4) \\
1.5-11.1 \\
(12)\end{array}$ & $\begin{array}{c}266(34.1) \\
16.7-44.3 \\
(12)\end{array}$ & $\begin{array}{c}47(6.0) \\
1.6-12.7 \\
(12)\end{array}$ & $\begin{array}{c}291(37.4) \\
27.0-47.5 \\
\quad(12)\end{array}$ & $\begin{array}{c}360(\mathbf{4 6 . 2}) \\
36.2-68.9 \\
(12)\end{array}$ & $\begin{array}{c}67(8.6) \\
2.8-15.0 \\
(12)\end{array}$ & $\begin{array}{c}49(6.3) \\
3.2-10.1 \\
(12)\end{array}$ & $\begin{array}{c}23(3.0) \\
0.0-6.3 \\
(10)\end{array}$ \\
\hline Kerman & 12 & 820 & $\begin{array}{c}23(2.8) \\
0.0-7.4 \\
(7)\end{array}$ & $\begin{array}{c}194(23.7) \\
15.1-30.1 \\
(12)\end{array}$ & $\begin{array}{c}336(41.0) \\
31.3-52.2 \\
(12)\end{array}$ & $\begin{array}{c}112(13.7) \\
7.0-22.8 \\
(12)\end{array}$ & $\begin{array}{c}395(48.2) \\
32.9-57.4 \\
(12)\end{array}$ & $\begin{array}{c}431(\mathbf{5 2 . 6}) \\
43.3-59.7 \\
(12)\end{array}$ & $\begin{array}{c}240(29.3) \\
20.0-42.6 \\
(12)\end{array}$ & $\begin{array}{c}132(16.1) \\
7.0-26.9 \\
(12)\end{array}$ & $\begin{array}{c}14(1.7) \\
0.0-4.1 \\
(7)\end{array}$ \\
\hline Khorasan & 14 & 868 & $\begin{array}{c}76(8.8) \\
0.0-22.2 \\
(10)\end{array}$ & $\begin{array}{c}157(18.1) \\
3.8-39.4 \\
(14)\end{array}$ & $\begin{array}{c}276(31.8) \\
8.3-54.2 \\
(14)\end{array}$ & $\begin{array}{c}83(9.6) \\
2.0-27.0 \\
(14)\end{array}$ & $\begin{array}{c}355(\mathbf{4 0 . 9}) \\
11.8-69.0 \\
(14)\end{array}$ & $\begin{array}{c}298(34.3) \\
11.3-63.5 \\
(14)\end{array}$ & $\begin{array}{c}259(29.8) \\
13.4-52.1 \\
\quad(14)\end{array}$ & $\begin{array}{c}52(6.0) \\
0.0-14.1 \\
(10)\end{array}$ & $\begin{array}{c}82(9.4) \\
0.0-17.5 \\
(13)\end{array}$ \\
\hline Khuzestan & 10 & 683 & $\begin{array}{c}64(9.4) \\
0.0-26.6 \\
(8)\end{array}$ & $\begin{array}{c}166(24.3) \\
11.8-50.0 \\
(10)\end{array}$ & $\begin{array}{c}261(38.2) \\
22.4-48.4 \\
(10)\end{array}$ & $\begin{array}{c}133(19.5) \\
1.5-37.1 \\
(10)\end{array}$ & $\begin{array}{c}290(42.5) \\
32.3-53.1 \\
(10)\end{array}$ & $\begin{array}{c}304(\mathbf{4 4 . 5}) \\
22.6-56.3 \\
(10)\end{array}$ & $\begin{array}{c}195(28.6) \\
16.2-44.3 \\
\quad(10)\end{array}$ & $\begin{array}{c}98(14.3) \\
0.0-34.4 \\
(9)\end{array}$ & $\begin{array}{c}17(2.5) \\
0.0-6.1 \\
(6)\end{array}$ \\
\hline Lorestan & 11 & 624 & $\begin{array}{c}26(4.2) \\
0.0-9.5 \\
(8)\end{array}$ & $\begin{array}{c}37(5.9) \\
0.0-12.3 \\
(10)\end{array}$ & $\begin{array}{c}160(25.6) \\
12.5-39.7 \\
(11)\end{array}$ & $\begin{array}{c}32(5.1) \\
0.0-14.0 \\
(9)\end{array}$ & $\begin{array}{c}189(30.3) \\
16.0-44.9 \\
(11)\end{array}$ & $\begin{array}{c}298(\mathbf{4 7 . 8}) \\
35.7-66.7 \\
(11)\end{array}$ & $\begin{array}{c}70(11.2) \\
0.0-24.6 \\
(9)\end{array}$ & $\begin{array}{c}20(3.2) \\
0.0-7.2 \\
(8)\end{array}$ & $\begin{array}{c}9(1.4) \\
0.0-6.0 \\
(6)\end{array}$ \\
\hline Tehran & 11 & 582 & $\begin{array}{c}21(3.6) \\
0.0-7.5 \\
\quad(9)\end{array}$ & $\begin{array}{c}88(15.1) \\
1.8-29.0 \\
(11)\end{array}$ & $\begin{array}{c}122(21.0) \\
0.0-40.3 \\
(10)\end{array}$ & $\begin{array}{c}31(5.3) \\
0.0-11.9 \\
(7)\end{array}$ & $\begin{array}{c}212(\mathbf{3 6 . 4}) \\
9.1-61.3 \\
(11)\end{array}$ & $\begin{array}{c}154(26.5) \\
7.3-40.3 \\
(11)\end{array}$ & $\begin{array}{c}99(17.0) \\
0.0-29.0 \\
(10)\end{array}$ & $\begin{array}{c}63(10.8) \\
2.1-21.0 \\
(11)\end{array}$ & $\begin{array}{c}54(9.3) \\
0.0-16.1 \\
\text { (9) }\end{array}$ \\
\hline Zanjan & 11 & 661 & $\begin{array}{c}52(7.9) \\
0.0-14.7 \\
(10)\end{array}$ & $\begin{array}{c}67(10.1) \\
0.0-22.2 \\
(10)\end{array}$ & $\begin{array}{c}135(20.4) \\
8.8-29.7 \\
(11)\end{array}$ & $\begin{array}{c}45(6.8) \\
0.0-15.9 \\
(9)\end{array}$ & $\begin{array}{c}198(30.0) \\
16.7-49.2 \\
(11)\end{array}$ & $\begin{array}{c}213(\mathbf{3 2 . 2}) \\
15.4-48.0 \\
(11)\end{array}$ & $\begin{array}{c}149(22.5) \\
8.3-38.0 \\
(11)\end{array}$ & $\begin{array}{c}29(4.4) \\
0.0-11.1 \\
(7)\end{array}$ & $\begin{array}{c}36(5.4) \\
1.8-9.5 \\
(11)\end{array}$ \\
\hline Average ${ }^{f}$ & 132 & 8,135 & $\begin{array}{c}572(7.0) \\
0.0-26.6 \\
(110)\end{array}$ & $\begin{array}{c}1,132(13.9) \\
0.0-50.0 \\
(127)\end{array}$ & $\begin{array}{c}2,195(27.0) \\
0.0-54.2 \\
(131)\end{array}$ & $\begin{array}{c}729(9.0) \\
0.0-37.1 \\
(116)\end{array}$ & $\begin{array}{c}2,895 \text { (35.6) } \\
9.1-69.0 \\
(132)\end{array}$ & $\begin{array}{c}2,795(34.4) \\
4.5-68.9 \\
(132)\end{array}$ & $\begin{array}{c}1,694(20.8) \\
0.0-52.1 \\
(129)\end{array}$ & $\begin{array}{c}477(5.9) \\
0.0-34.4 \\
(88)\end{array}$ & $\begin{array}{c}412(5.1) \\
0.0-31.5 \\
(93)\end{array}$ \\
\hline
\end{tabular}

${ }^{a}$ Identification was based on serological reactions (enzyme-linked immunosorbent assay). The highest incidence of virus infections in each province is shown in bold.

${ }^{\mathrm{b}}$ Alfalfa mosaic virus (AlMV), Potato leafroll virus (PLRV), Potato virus A (PVA), Potato virus M (PVM), Potato virus $S$ (PVS), Potato virus Y (PVY),

Potato virus $X$ (PVX), Tomato yellow fruit ring virus (TYFRV), and Eggplant mottled dwarf virus (EMDV).

${ }^{\mathrm{c}}$ Number of infected potato leaf samples. (Average of percent virus incidence.)

${ }^{\mathrm{d}}$ Range of percent virus incidence.

${ }^{\mathrm{e}}$ Number of fields with virus infection.

${ }^{\mathrm{f}}$ Incidence of each virus in the surveyed provinces. 
was greater than or equal to three times the average value of negative (healthy) samples.

Host range studies. For each virus tested, three potato leaf samples collected from Hamedan province, one of the main provinces for potato production, that had positive reactions in ELISA were selected and further evaluated in a host range study. Plant species used were Gomphrena globosa (Asteraceae), Chenopodium amaranticolor and Ch. quinoa (Chenopodiaceae), Phaseolus vulgaris cv. Bountiful and Vigna unguiculata (Fabaceae), Datura metel, D. stramonium, Lycopersicon esculentum, Nicotiana glutinosa, $N$. rustica, $N$. tabacum cv. Samsun, N. tabacum cv. White Burley, Petunia hybrida, Physalis floridana, and Solanum tuberosum cv. Agria (Solanaceae). For mechanical inoculations, the selected leaf samples were ground in $0.1 \mathrm{M}$ Na-phosphate buffer ( $\mathrm{pH} 7.0)$ containing $0.2 \%$ sodium sulfite. For aphid transmission of PLRV, green peach aphids (Myzus persicae) were used. The aphids were maintained in insect-proof cages on turnip plants (Brassica rapa). After a 2-h starvation period, individual aphids were transferred to PLRV-positive leaf samples (i.e., infected) as confirmed through ELISA. After 2 to $3 \mathrm{~h}$, the aphids were touched with a camelhair brush to induce retraction of their stylets, then transferred with the brush to healthy test plants. After 2 days, the seedlings were sprayed with Primicarb (Bayer, Germany) as recommended by the manufacturer. At least two plants of each species or cultivar named above were inoculated. The tests were repeated twice, or more if the results were negative or uncertain. The plants were kept in a greenhouse with a 12-h light period, a temperature of $25 \pm 5^{\circ} \mathrm{C}$ and 50 to $70 \%$ relative humidity, and observed 1 to 3 weeks or longer after inoculation. ELISA and symptomology were used to assess the presence of viruses in inoculated plants.

Determination of insect fauna in potato fields. The insect fauna present in the 12 fields surveyed in Hamedan were collected using a standard 15-in.-diameter sweep net in early September 2003. A total of 50 to 100 sweeps were taken in 5 to 10 randomly selected areas in each field, depending on the field size, without sweeping from weeds grown in margins of the fields. Also, two ware potato fields (grown for fresh and processing markets) in the Bahar area of Hamedan were selected and their aphid populations determined. In this case, aphids were collected from the potato fields from late May through September using yellow pan traps and plant sampling. Pan traps were placed on the borders of the fields (two traps per field) to enable more efficient capture of alate aphids (18). Aphids captured in the traps were collected every 2 weeks. Moreover, aphids on 20 randomly selected potato plants in each of the two fields were collected at 2-week intervals. All trapped insects initially were preserved in $70 \%$ ethanol for later counting and identification (kindly by A. Rezwani and M. Taghizadeh, Plant Pests and Diseases Research Institute, Iran).

\section{RESULTS}

Plant sampling. Symptoms of virus infection were seen in 132 fields, representing all fields in the 11 provinces surveyed. Incidence of symptomatic plants varied largely, not only among regions but also among fields in the same region, especially in Khorasan province. Plants in Kerman province generally showed higher levels of disease symptoms, whereas those in Ardabil showed lower levels. Symptoms observed included mosaic, mottling, rugosity, crinkling, chlorosis, necrosis, and stunting. Mosaic and rugosity were the most common symptoms observed in potato fields in different provinces of Iran; the incidence of these symptoms in the collected samples was 21.0 and $14.0 \%$, respectively.

Results of cross-reactivity assays showed that there was no cross-reaction among the detection systems of related viruses in the genus Potyvirus or Carlavirus (data not shown). Based on ELISAs of the leaf samples, viral disease incidence in decreasing order was PVS (35.6\%), PVY (34.4\%), PVA (27.0\%), PVX (20.8\%), PLRV (13.9\%), PVM (9.0\%), AlMV (7.0\%), TYFRV (5.9\%), and EMDV $(5.1 \%)$ (Table 1). PVS was the most prevalent virus among those tested. This virus was detected in 2,895 samples collected from all fields (132 fields) surveyed. The incidence of PVS in the provinces visited ranged from $20.8 \%$ in Ardabil to $48.2 \%$ in Kerman. Plants infected with PVS or PVM alone usually did not exhibit typical virus disease symptoms.
PVY was the second most predominant virus; it was found in $100 \%$ of the fields visited. Mosaic, mottling, crinkling, and necrosis were most often associated with PVY infections. Except for necrosis, the symptoms observed in PVA-infected plants were similar to those for PVY. Plants infected with PVX sometimes exhibited mottling symptoms; however, plants with mixed infections of PVY and PVX showed rugose mosaic symptoms. The incidence of PVA or PVX was lower than that of PVY in all provinces surveyed, except for Ardabil and Azarbayejan-e-sharqi, where PVA and PVX, respectively, had higher incidence than PVY (Table 1).

In most PLRV-infected plants, leaves rolled inward and turned pale yellow, the entire plant became rigid, and the leaves were dry and brittle. This virus was most prevalent in Khuzestan $(24.3 \%)$ followed by Kerman $(23.7 \%)$ and Esfahan $(22.9 \%)$ provinces.

Potato plants infected with EMDV showed two types of symptoms: chlorosis with severe stunting and axial folding of young leaflets combined with systemic necrosis of top and lateral young shoots. Tuber symptoms in EMDV-infected potatoes included malformation, hardness, and cracked skin. Of the 412 EMDV-infected samples, 112 were from Chaharmahal-vabakhtiyari, comprising $27.2 \%$ of the total infections. Based on symptom evaluations, the number of EMDV-infected potato plants in margins of affected fields was higher than in other locations in the same fields.

AlMV was detected mostly in Hamedan province $(14.6 \%)$, where alfalfa fields are frequently located near potatoes. Bright yellow blotching and mosaic (calico) were observed on AlMV-infected potatoes. Also,

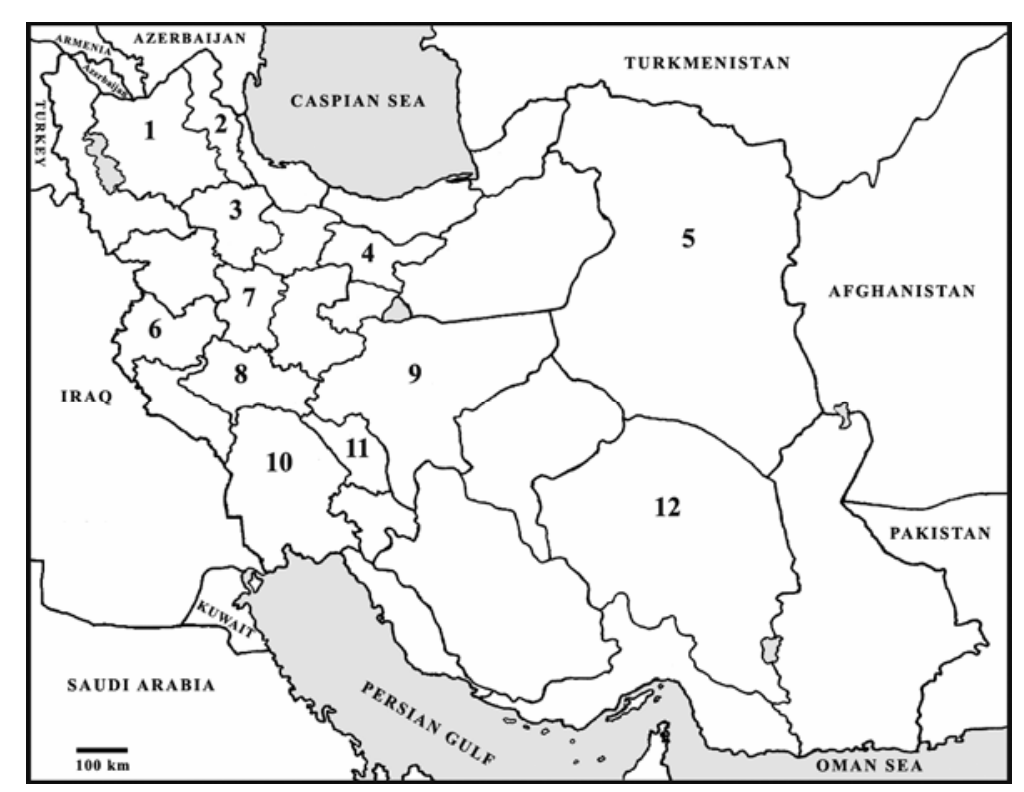

Fig. 1. Map of Iran showing the location of provinces (1 to 12) where potato crops were surveyed for the presence of viruses infecting potatoes. 1: Azarbayejan-e-sharqi, 2: Ardabil, 3: Zanjan, 4: Tehran, 5: Khorasan, 6: Kermanshah, 7: Hamedan, 8: Lorestan, 9: Esfahan, 10: Khuzestan, 11: Chaharmahal-vabakhtyiari, 12: Kerman. Courtesy of Farzadfar et al. (23). 
some samples showed stem and tuber necrosis. Field symptoms associated with TYFRV included chlorotic spots and leaf and stem necrosis. The incidence of this virus ranged from $0.0 \%$ (Ardabil) to $16.1 \%$ (Kerman). A high population of Thrips tabaci also was observed in some of the TYFRV-affected fields. Assays for BCTV in symptomatic collected samples indicated that the virus was present in potato samples (31 out of 47 samples) collected from three fields in Kermanshah. BCTVpositive samples showed stunting, chlorosis, and leaf deformation. The affected plants had cupped and bunched leaflets as well as stiffed and hardened stems. However, the plants were frequently infected with more than one virus, so it was not possible to correlate particular symptoms with a specific virus.

Our data showed that all 132 fields surveyed had virus infections, ranging from
28.8 to $98.6 \%$ incidence, with the overall incidence of $75.2 \%$. Serological assays indicated that the highest incidence of virus infection occurred in Kerman (93.2\%). In contrast, overall viral disease incidence in Ardabil was the lowest $(56.7 \%)$ among all provinces surveyed (Table 2). Overall, 25.0 and $50.2 \%$ of the collected potato leaf samples had single and mixed infections, respectively. In Ardabil, more plants were infected with a single virus than with multiple viruses, and in Azarbayejan-e-sharqi mixed and single infections occurred at similar frequencies (Table 2). Otherwise, mixed infections were more prevalent than single infections. Mixed infections involving two or more viruses were found in all the fields surveyed. In five fields in Chahrmahal-vabakhtiyari, Khorasan, Khuzestan, and Zanjan provinces, mixed infections involving seven viruses were detected. High levels of

Table 2. Percentage of single, mixed, and overall virus infections occurring in potato fields in different provinces of Iran ${ }^{\mathrm{a}}$

\begin{tabular}{|c|c|c|c|c|c|}
\hline Province & $\begin{array}{l}\text { No. of } \\
\text { fields }\end{array}$ & $\begin{array}{c}\text { No. of } \\
\text { samples }\end{array}$ & $\begin{array}{c}\text { Single } \\
\text { infections }\end{array}$ & $\begin{array}{c}\text { Mixed } \\
\text { infections }\end{array}$ & Overall $^{b}$ \\
\hline Ardabil & 14 & 884 & $\begin{array}{c}344(38.9)^{\mathrm{c}} \\
23.0-51.7^{\mathrm{d}} \\
(14)^{\mathrm{e}}\end{array}$ & $\begin{array}{c}156(17.6) \\
1.5-31.4 \\
(14)\end{array}$ & $\begin{array}{c}500(56.6) \\
28.8-74.3 \\
(14)\end{array}$ \\
\hline Azarbayejan-e-sharqi & 12 & 687 & $\begin{array}{c}197(28.7) \\
15.6-40.9 \\
(12)\end{array}$ & $\begin{array}{c}201(\mathbf{2 9 . 3}) \\
11.4-55.7 \\
(12)\end{array}$ & $\begin{array}{c}398(57.9) \\
31.1-81.4 \\
(12)\end{array}$ \\
\hline Chaharmahal-va-bakhtiyari & 12 & 734 & $\begin{array}{c}177(24.1) \\
5.6-44.4 \\
(12)\end{array}$ & $\begin{array}{c}408(\mathbf{5 5 . 6}) \\
23.3-88.9 \\
(12)\end{array}$ & $\begin{array}{c}585(79.7) \\
56.9-95.9 \\
(12)\end{array}$ \\
\hline Esfahan & 13 & 813 & $\begin{array}{c}223(27.4) \\
19.0-44.4 \\
(13)\end{array}$ & $\begin{array}{c}443(\mathbf{5 4 . 5}) \\
27.0-67.2 \\
(13)\end{array}$ & $\begin{array}{c}666(81.9) \\
71.4-88.3 \\
(13)\end{array}$ \\
\hline Hamedan & 12 & 779 & $\begin{array}{c}204(26.2) \\
18.8-32.8 \\
(12)\end{array}$ & $\begin{array}{c}404(\mathbf{5 1 . 9}) \\
41.7-67.2 \\
(12)\end{array}$ & $\begin{array}{c}608(78.0) \\
68.3-86.9 \\
(12)\end{array}$ \\
\hline Kerman & 12 & 820 & $\begin{array}{c}113(13.8) \\
2.9-30.6 \\
(12)\end{array}$ & $\begin{array}{c}651(\mathbf{7 9 . 4}) \\
57.6-91.0 \\
(12)\end{array}$ & $\begin{array}{c}764(93.2) \\
86.8-98.6 \\
(12)\end{array}$ \\
\hline Khorasan & 14 & 868 & $\begin{array}{c}162(18.7) \\
5.6-36.7 \\
(14)\end{array}$ & $\begin{array}{c}515(\mathbf{5 9 . 3}) \\
28.3-90.5 \\
(14)\end{array}$ & $\begin{array}{c}677(78.0) \\
56.9-96.8 \\
(14)\end{array}$ \\
\hline Khuzestan & 10 & 683 & $\begin{array}{c}85(12.4) \\
0.0-31.3 \\
(9)\end{array}$ & $\begin{array}{c}482(\mathbf{7 0 . 6}) \\
49.3-87.5 \\
(10)\end{array}$ & $\begin{array}{c}567(83.0) \\
74.2-92.9 \\
(10)\end{array}$ \\
\hline Lorestan & 11 & 624 & $\begin{array}{c}210(33.7) \\
18.5-48.0 \\
(11)\end{array}$ & $\begin{array}{c}266(\mathbf{4 2 . 6}) \\
17.9-62.3 \\
(11)\end{array}$ & $\begin{array}{c}476(76.3) \\
60.7-84.1 \\
(11)\end{array}$ \\
\hline Tehran & 11 & 582 & $\begin{array}{c}162(27.8) \\
9.5-48.1 \\
(11)\end{array}$ & $\begin{array}{c}252(\mathbf{4 3 . 3}) \\
4.2-77.4 \\
(11)\end{array}$ & $\begin{array}{c}414(71.1) \\
45.8-87.2 \\
(11)\end{array}$ \\
\hline Zanjan & 11 & 661 & $\begin{array}{c}155(23.4) \\
17.4-34.6 \\
(11)\end{array}$ & $\begin{array}{c}305(\mathbf{4 6 . 1}) \\
21.2-73.0 \\
(11)\end{array}$ & $\begin{array}{c}460(69.6) \\
50.0-92.1 \\
(11)\end{array}$ \\
\hline Average $^{f}$ & 132 & 8,135 & $\begin{array}{c}2,032(25.0) \\
0.0-51.7 \\
(131)\end{array}$ & $\begin{array}{c}4,083(\mathbf{5 0 . 2}) \\
1.5-91.0 \\
(132)\end{array}$ & $\begin{array}{c}6,115(75.2) \\
28.8-98.6 \\
(132)\end{array}$ \\
\hline
\end{tabular}

${ }^{a}$ Results were obtained through serological assays (enzyme-linked immunosorbent assay). The highest incidence of virus infections in each province is shown in bold.

${ }^{b}$ Total virus incidence in each province calculated on the basis of single or mixed virus infections found in the collected samples.

${ }^{c}$ Number of infected potato leaf samples. (Average of percent virus incidence.)

${ }^{\mathrm{d}}$ Range of percent virus incidence.

${ }^{\mathrm{e}}$ Number of fields with virus infection.

${ }^{\mathrm{f}}$ Incidence of virus infection in the surveyed provinces.

mixed infections were found between PVX and PVS (8.6\%), and PVX and PVY $(7.6 \%)$. Mixed infections of EMDV with PVS or PVY (incidence: 2.3 and 1.7\%, respectively) were more prevalent relative to other virus combinations, and were at similar levels to mixed infections of TYFRV with PVS $(2.7 \%)$ and PVY (2.4\%). Co-infection of samples with PVS and PVY, PVA and PVY, and PVA and PVS, the aphid-vectored virus/virus combinations, occurred with the highest incidence, $15.3,13.8$, and $12.8 \%$, respectively.

Host range studies. To confirm serological diagnoses, experimental host range determinations for selected isolates of viruses were determined by mechanical or aphid inoculations of 15 species or cultivars (Table 3 ). The results of these host range studies and the symptoms associated with specific viruses were similar to those of earlier reports $(4,7,10,16,26,31,40,42$, 44,52,53). As expected, inoculation with AlMV isolates produced local lesions on $V$. unguiculata and Ch. amaranticolor, and systemic infection on $N$. tabacum cvs. Samsun and White Burley, as well as $N$. glutinosa. The EMDV isolates induced chlorotic local lesions followed by systemic infection on N. glutinosa, and systemically infected $N$. rustica. PVA and PVY had the same host range and produced similar symptoms, with the only difference being that PVY caused a systemic infection on $L$. esculentum. The PVM isolates systemically infected $D$. metel and L. esculentum, and induced local lesions on C. quinoa and P. vulgaris cv. Bountiful. In contrast, our PVS isolates did not infect $P$. vulgaris cv. Bountiful and $L$. esculentum. Mechanical inoculation of both PVM and PVS resulted in a systemic infection, without observable symptoms on S. tuberosum cv. Agria. The PVX isolated from potato caused chlorotic local lesions on G. globosa and systemically infected all Nicotiana species and cultivars used in this study. Our TYFRV isolates from potato locally infected $P$. hybrida and caused necrotic local lesions, which are characteristic symptoms produced by tospoviruses. Moreover, systemic infections were produced in D. metel, D. stramonium, $N$. glutinosa, and $N$. rustica preceded by necrotic or chlorotic lesions. The PLRV isolates were transmitted by aphids to D. stramonium, Phy. floridana and $S$. tuberosum cv. Agria, where they incited systemic infections.

Determination of insect fauna in potato fields. Agallia vorobjevi, Circulifer tenellus, and C. opacipennis (Cicadellidae) were found in the 12 surveyed fields of Hamedan. In this survey, 36 other insect species belonging to seven familiesPsyllidae, Cercopidae, Cicadellidae, Cixidae, Delphacidae, Dictyopharidae, and Tettigometridae-were also identified (data not shown).

Aphid population studies in the two selected potato fields in Hamedan (Bahar) 
indicated the presence of aphid species, including Acyrthosiphon pisum, Aphis craccivora, A. fabae, A. gossypii, A. nasturtii, Aulacorthum circumflexum, Au. solani, Macrosiphun euphorbiae, and Myzus persicae (Aphididae). The dominant aphid in these fields was Therioaphis trifolii (Drepanosiphidae). First alate aphids were captured in early May, and the highest population of aphids was recorded in early August. We also found A. fabae, A. gossypii, A. nasturtii, Au. solani, Ma. euphorbiae, and $M$. persicae as colonizing aphid species on potato plants in these fields.

\section{DISCUSSION}

The occurrence, distribution, and incidence of 10 viruses infecting potato plants in Iran were assessed using ELISA, symptomatology, and host range. As expected, ELISA provided more accurate and consistent results than the other methods, especially for distinguishing between PVM and PVS (genus Carlavirus), and PVA and PVY (family Potyviridae), which have similar host ranges $(4,16,52,53)$. PVS, the most prevalent virus found in the surveyed fields, is readily transmitted in seed potatoes, mechanically by contact with diseased plants, and for some strains, by aphids in a nonpersistent manner (29). Based on ELISA, PVY was present in all potato fields surveyed. The high incidence and wide distribution of PVY in all surveyed provinces probably reflects both a very high inoculum reservoir (e.g., infected tubers) and the prevalence and efficiency of aphid vectors in transmitting PVY. The host ranges of the three selected PVY isolates studied were similar to those described for $\mathrm{PVY}^{\mathrm{O}}$ (16). The occurrence of $\mathrm{O}, \mathrm{N}$, and $\mathrm{C}$ strains of this virus has been previously reported from Iran mainly based on biological properties $(15,36,47)$, and preliminary observations indicate the $\mathrm{PVY}^{\mathrm{O}}$ strain is prevalent in Esfahan and Khuzestan provinces $(15,36)$. However, more studies are needed to determine the incidence and distribution of PVY strains in Iran.

In EMDV-infected plants, symptoms of chlorosis and severe stunting of the entire plant may be due to secondary infections through infected tubers early in the growing season. Axial folding of young leaflets, systemic necrosis of top and lateral young shoots are produced in plants primarily infected with this virus after vector transmission (14). EMDV was found mainly in Chaharmahal-va-Bakhtiyari (15.3\%), Khorasan (9.4\%), and Esfahan (6.9\%). The vector for EMDV, Agallia vorobjevi (3), is widespread in these provinces (data not shown). This virus was first reported on potato in Iran from Chaharmahal-vaBakhtiyari (14) and subsequently from Esfahan, Fars, and Tehran provinces $(2,25)$. In a survey done in early summer of 2004, we found EMDV-infection of cucumber plants and $A$. vorobjevi in fields in Azarbayejan-sharqi, Tehran, and Zanjan (unpublished data). Our results suggest that EMDV infections are not epidemic in Iranian potato fields, consistent with the limited activity of this vector in the area.

There are few recent reports on Tospovirus infection of potatoes in the world. Tomato spotted wilt virus and Impatiens necrotic spot virus were previously reported to infect potatoes naturally (12). In this study, almost $6.0 \%$ of the potato samples reacted to TYFRV-specific antibodies, a recently proposed species in the genus Tospovirus $(54,55)$. In host range studies, some differences were found among TYFRV isolates collected from the provinces surveyed (data not shown). Further investigation of the biological and molecular properties of different TYFRV isolates in Iran may reveal considerable variation among isolates of this virus.

The results showed that disease incidence as related to each virus and geographical area surveyed is quite variable. AlMV, EMDV, PVX, PVY, and TYFRV were previously reported from other hosts in Iran $(2,19,26,27,33,41)$, and these hosts may serve as alternative virus hosts. For example, the relatively high incidence of AlMV in Hamedan may be related to the presence of alfalfa fields near potato crops in this province. High populations of the aphid vector Therioaphis trifolii may also play a role in AlMV incidence in Hamedan.

The study of insect fauna in potato fields of Hamedan indicated the presence of insect vectors such as Circulifer tenellus and $C$. opacipennis, and $A$. vorobjevi, which transmit BCTV and EMDV, respectively, in a persistent manner $(3,50)$. Moreover, some potential aphid vectors of AlMV, PLRV, PVM, PVS, and PVY were identified in this area. We found some aphid species, e.g., M. persicae, colonizing potato plants in the fields surveyed in Hamedan (Bahar), consistent with earlier reports (48). However, the important role of noncolonizing winged aphids, especially in spreading of stylet-borne viruses, is well documented (30) and has been previously described as a factor involved in

Table 3. Reactions of indicator host plant species to viruses infecting potatoes ${ }^{\mathrm{a}}$

\begin{tabular}{|c|c|c|c|c|c|c|c|c|c|}
\hline \multirow[b]{2}{*}{ Indicator plant } & \multicolumn{9}{|c|}{ Virus $^{b, c}$} \\
\hline & AIMV & EMDV & PLRV & PVA & PVM & PVS & PVX & PVY & TYFRV \\
\hline \multicolumn{10}{|l|}{ Amaranthaceae } \\
\hline Gomphrena globosa & cll & cll & $\mathrm{n}$ & - & nll & nll & cll & - & nll \\
\hline \multicolumn{10}{|l|}{ Chenopodiaceae } \\
\hline Chenopodium amaranticolor & cll & $\mathrm{n}$ & $\mathrm{n}$ & $\mathrm{n}$ & $\mathrm{n}$ & cll & cll & - & nll \\
\hline C. quinoa & cll & cll & $\mathrm{n}$ & $\mathrm{n}$ & cll & cll & cll & cll & nll \\
\hline \multicolumn{10}{|l|}{ Fabaceae } \\
\hline Phaseolus vulgaris cv. Bountiful & cll, mos & - & $\mathrm{n}$ & - & cll & - & - & - & nll \\
\hline Vigna unguiculata cv. Mashad & cll, mos & - & $\mathrm{n}$ & - & $\mathrm{n}$ & $\mathrm{n}$ & - & - & nll \\
\hline \multicolumn{10}{|l|}{ Solanaceae } \\
\hline Datura metel & $\mathrm{n}$ & - & $\mathrm{n}$ & $\mathrm{n}$ & cll, su & $\mathrm{s}$ & $\mathrm{n}$ & $\mathrm{vc}$ & cll, mot, smn, stn \\
\hline D. stramonium & $\mathrm{n}$ & - & chl & - & $\mathrm{n}$ & $\mathrm{n}$ & mot & - & $\mathrm{cll}$, mot, sn \\
\hline Lycopersicon esculentum & $\mathrm{s}$ & $\mathrm{s}$ & $\mathrm{n}$ & - & $\mathrm{s}$ & - & su & mot & $\mathrm{n}$ \\
\hline N. glutinosa & $\operatorname{mos}$ & cll, sn & $\mathrm{n}$ & mot & - & - & $\operatorname{mos}$ & $\mathrm{vc}, \operatorname{mos}$ & nll, sn \\
\hline N. rustica & mot & scs, vy, ld, su & $\mathrm{n}$ & $\mathrm{n}$ & $\mathrm{n}$ & $\mathrm{n}$ & $\mathrm{s}$ & $\mathrm{s}$ & cll, sn \\
\hline N. tabacum cv. Samsun & cll, s & mos, vy, su & $\mathrm{n}$ & $\mathrm{vc}$, mot & - & - & $\mathrm{s}$ & $\mathrm{vc}, \mathrm{mot}$ & $\mathrm{n}$ \\
\hline N. tabacum cv. White Burley & mot & mos, vy, su & $\mathrm{n}$ & $\mathrm{vc}$ & - & - & $\mathrm{s}$ & mot & $\mathrm{n}$ \\
\hline Petunia hybrida & $\mathrm{s}$ & $\mathrm{n}$ & $\mathrm{n}$ & $\mathrm{n}$ & $\mathrm{n}$ & $\mathrm{n}$ & $\mathrm{n}$ & $\mathrm{n}$ & nll \\
\hline Physalis floridana & $\mathrm{s}$ & $\mathrm{n}$ & chl, su & $\mathrm{n}$ & $\mathrm{n}$ & - & $\mathrm{n}$ & $\mathrm{cll}, \mathrm{mot}$ & $\mathrm{n}$ \\
\hline Solanum tuberosum cv. Agria & $\mathrm{ca}$ & chl, sn & $\operatorname{lr}$ & $\operatorname{mos}$ & $\mathrm{s}$ & $\mathrm{s}$ & $\mathrm{s}$ & $\operatorname{mos}$ & $\mathrm{cll}, \mathrm{sn}$ \\
\hline
\end{tabular}

a Enzyme-linked immunosorbent assay (ELISA) used to confirm the presence of each virus in indicator host plants.

b Alfalfa mosaic virus (AlMV), Eggplant mottled dwarf virus (EMDV), Potato leafroll virus (PLRV), Potato virus A (PVA), Potato virus M (PVM), Potato virus $S$ (PVS), Potato virus X (PVX), Potato virus $Y$ (PVY), and Tomato yellow fruit ring virus (TYFRV).

${ }^{\mathrm{c}}$ ca, yellow mosaic or calico; cll, chlorotic local lesion; chl, chlorosis; ld, leaf deformation; lr, leaf rolling; mos, mosaic; mot, mottling; n, not determined; nll, necrotic local lesion; s, systemic (symptomless); scs, systemic chlorotic spot; sn, systemic necrosis; stn, stem necrosis; su, stunting; vc, vein clearing; vy, vein yellowing; -, no reaction (when tested by ELISA and also no visible symptoms). 
PVY epidemics occurring in Europe $(17,28,48)$. The high incidence of nonpersistently transmitted viruses on ware potatoes in some regions, particularly in Bahar area, may be related to early-season vector activity. In these regions, more aphids survive in the moderate winters, and potato crops are colonized earlier in the growing season (personal observations). Similarly, virus disease incidence in Kerman was recorded at high levels (Tables 1 and 2), especially in the Jiroft area where winters are moderate, giving rise to high populations of aphids. Results from this study also show that mixed infections occurred in high frequencies in all provinces (Table 2). A more detailed survey of insect populations and transmission studies would be useful in trying to identify how these viruses are spreading in Iran.

The incidence of PVY and PVS in the surveyed fields was high, and up to $70 \%$ of the crops were found to be infected (Table 1). Most PVY spread occurs from infected to healthy plants within the same potato field, rather than by winged aphids transmitting viruses from other fields $(8,11,51)$. Thus, it is likely that most virus infections in the Iranian ware potato fields originated from infected seed tubers that were present in the seed stock. We found that virus incidence in large fields, which were planted with certified seeds, was lower than in small fields grown with uncertified seeds. About half of Iranian ware potato farmers produce their own seed tubers of unknown quality (personal observations).

Most cultivated potatoes in Iran originate from seed tubers imported from the Netherlands. Most of the tolerance criteria for inspection of the seed potatoes in the Iranian seed potato certification process are based on criteria established for the Netherlands (43). Therefore, tolerance for virus infection of basic seed potatoes, including the Super (S), Super Elite (SE), and Elite (E) classes, is 0.5 to $1 \%$ in postharvest controls. Imported seeds also are propagated at least three to five times before being introduced to ware potato production; therefore, higher levels of insectvectored viruses may occur in ware potato crops. Similar observations were reported earlier for PVY infections $(5,35)$. The difficulties associated with postharvest ELISAs limit their use in developing a reliable seed certification procedure in Iran. Entry of seed tuber lots into the seed program depends only on visual and field inspections in Iran. This coupled with the finding of infections by PVM, PVS, and/or PVX that did not show typical virus disease symptoms make it likely that the rate of virus infection of seed tuber lots is underrated.

This study seems to indicate that the low yields of potato in Iran may be, at least in part, due to the high level of virus infections $(75.2 \%)$. Similar results have been previously reported from other countries, e.g., the potato yield recorded in Lebanon and Uganda in 1999 were 19 and $7 \mathrm{t} / \mathrm{h}$, with the overall virus incidence of 52.7 and $88.3 \%$, respectively $(1,20,34)$. We showed that viruses are widespread in potatoes in Iran; they are often found in mixed infections, and infections caused by these viruses are not always visually detectable. However, many questions remain unanswered that relate to epidemiological and managerial aspects of virus disease control. In this respect, it seems justifiable to place increasing emphasis on studying factors influencing the structure of virus epidemics in potato crops and optimizing quality control checks.

\section{ACKNOWLEDGMENTS}

This work was supported by the Plant Virology Department of PPDRI (Tehran). We are grateful to S. Winter, N. Shahraeen, and M. Bahar who kindly provided some of the antisera and positive samples that were used in this study. We thank A. Rezwani and $\mathrm{M}$. Taghizadeh for identification of insects and H. R. Mojdehi for his kindly advice. This research was part of the Ph.D. thesis of the third author and carried out under project nos. 2-009-100000-11$0000-83054,83055$, and 83060 of PPDRI.

\section{LITERATURE CITED}

1. Abou-Jawdah, Y., Sobh, H., and Saad, A. 2001. Incidence of potato virus diseases and their significance for a seed certification program in Lebanon. Phytopathol. Mediterr. 40:113-118.

2. Babaie, Gh., and Izadpanah, K. 2002. Host range, distribution, isolates and transmission trials of Eggplant mottled dwarf virus. Iran. Plant Pathol. 38:235-250.

3. Babaie, Gh., and Izadpanah, K. 2003. Vector transmission of Eggplant mottled dwarf virus in Iran. J. Phytopathol. 151:679.

4. Bartels, R. 1971. Potato virus A. AAB Descriptions of Plant Viruses, No. 54.

5. Beemster, A. B. R. 1979. Acquisition of potato virus Yn by Myzus persicae from primarily infected 'Bintje' potato plants. Neth. J. Plant Pathol. 85:75-81.

6. Beemster, A. B. R., and de Bokx, J. A. 1987. Survey of properties and symptoms. Pages 84113 in: Viruses of Potato and Seed Potato Production. J. A. de Bokx and J. P. H. van der Want, eds. Pudoc, Wageningen, The Netherlands.

7. Bercks, R. 1970. Potato virus X. AAB Descriptions of Plant Viruses, No. 4.

8. Broadbent, L., Burt, P. E., and Heathcote, G. D. 1956. The control of potato virus diseases by insecticides. Ann. Appl. Biol. 44:256-273.

9. Brunt, A. A. 2001. Potato virus M (PVM; Genus Carlavirus). Pages 101-107 in: Virus and Virus-like Diseases of Potatoes and Production of Seed Potatoes. G. Loenbenstein, P. H. Berger, A. A. Brunt, and R. H. Lawson, eds. Kluwer Academic Publishers, The Netherlands.

10. Brunt, A. A., Crabtree, K., Dallwitz, M. J., Gibbs, A. J., and Watson, L. 1995. Viruses of plants: Description and lists from the VIDE database. CAB International, Wallingford, UK.

11. Cadman, C. H., and Chambers, J. 1960. Factors affecting the spread of aphid borne viruses in potato in eastern Scotland. III. Effects of planting date, roguing and age of crop on the spread of potato leaf roll and Y viruses. Ann. Appl. Biol. 48:729-738

12. Campbell, L. R., Robb, K. L., and Ullman, D. E. 2005. The complete Tospovirus resource page. Kansas State University. Online publication.

13. Clark, M. F., and Adams, A. N. 1977. Charac- teristics of the microplate method of enzymelinked immunosorbent assay for the detection of plant viruses. J. Gen. Virol. 34:475-483.

14. Danesh, D., and Lockhart, B. E. L. 1989. Eggplant mottled dwarf virus in potato in Iran. Plant Dis. 73:856-858.

15. Danesh, D., Soleimanian, S., Filsouf, F., and Dehghan, M. 1992. Incidence of four potato viruses in the Esfahan region of Iran. Iran. J. Plant Pathol. 28:1.

16. De Bokx, J. A., and Hutinga, H. 1981. Potato virus Y. AAB Descriptions of Plant Viruses, No. 242.

17. De Box, J. A., and Piron, P. G. M. 1990. Relative efficiency of a number of aphid species in the transmission of potato virus $\mathrm{Y}^{\mathrm{N}}$ in the Netherlands. Neth. J. Plant Pathol. 96:237-246.

18. DiFonzo, C. D., Ragsdale, D. W., Radcliffe, E. B., Gudmestad, N. C., and Secor, G. A. 1996. Crop borders reduce potato virus $\mathrm{Y}$ incidence in seed potato. Ann. Appl. Biol. 129:289-302.

19. Elahinia, S. A., and Shahraeen, N. 1998. Serodiagnosis of a strain of potato virus Y (PVY) in commercial tobacco cultivars Coker-347 in Gilan province. Page 209 in: Proc. Plant Prot. Congr. Iran, 13th.

20. FAO. 1999. FAOSTAT Database results from FAO website. Food and Agriculture Organization of the United Nations.

21. FAO. 2000. FAOSTAT Database results from FAO website. Food and Agriculture Organization of the United Nations.

22. FAO. 2004. FAOSTAT Database results from FAO website. Food and Agriculture Organization of the United Nations.

23. Farzadfar, Sh., Golnaraghi, A. R., and Pourrahim, R., eds. 2002. Plant viruses of Iran (in English). Saman Co.,Tehran, Iran.

24. Farzadfar, Sh., Pourrahim, R., Golnaraghi, A. R., and Ahoonmanesh, A. 2006. Distribution and incidence of some aphid and leafhopper transmitted viruses infecting sugar beets in Iran. Plant Dis. 90:252-258.

25. Farzadfar, Sh., Pourrahim, R., and Shahraeen, N. 2000. Detection of Eggplant mottled dwarf virus in potato fields of Damavand. Page 313 in: Proc. Plant Prot. Congr. Iran, 14th.

26. Ghotbi, T., Shahraeen, N., and Winter, S. 2005. Occurrence of tospoviruses in ornamental and weed species in Markazi and Tehran provinces in Iran. Plant Dis. 89:425-429.

27. Golnaraghi, A. R., Shahraeen, N., Pourrahim, R., Farzadfar, Sh., and Ghasemi, A. 2004. Occurrence and relative incidence of viruses infecting soybeans in Iran. Plant Dis. 88:10691074.

28. Harrington, R., and Gibson, R. W. 1989. Transmission of potato virus $\mathrm{Y}$ by aphids trapped in potato crops in southern England. Potato Res. 32:167-174.

29. Hooker, W. J. 1990. Compendium of Potato Diseases. American Phytopathological Society, St. Paul, MN

30. Hull, R. 2002. Matthews' Plant Virology. Academic Press, New York.

31. Jaspars, E. M. J., and Bos, L. 1980. Alfalfa mosaic virus. AAB Descriptions of Plant Viruses, No. 229

32. Jeffries, C. J. 1998. Potato. FAO/IPGRI technical guidelines for the safe movement of germplasm. No. 19, FAO and IPGRI, Rome.

33. Kaiser, W. J., Mossahebi, G. H., and Okhovat, M. 1971. Alternate hosts of viruses affecting food legumes in Iran. Iran. J. Plant Pathol. $7: 85$.

34. Kakuhenzire, R., Hakiza, J. J., Mateeka, B., Lemaga, B., Salazar, L., and Olanya, M. 2000. Incidence and importance of potato viruses in southwestern Uganda. Afr. Potato Assoc. Conf. Proc. 5:285-290.

35. Katis, N., and Gibson, R. W. 1988. Primarily infected potato plants as sources of potato virus Y. Acta Phytopathol. Entomol. Hung. 23:67-72. 
36. Khakvar, R. 2000. Identification of important viral diseases of potato in Khuzestan province. M.Sc. thesis. Department of Plant Protection, College of Agriculture, Shahid Chamran University, Ahwas, Iran.

37. Khakvar, R., Pourrahim, R., and Shamsbakhsh, M. 2000. Study on six potato viruses in Khuzestan provience. Page 312 in: Proc. Plant Prot. Congr. Iran, 14th.

38. Loebenstein, G. 2001. Potato leaf roll virus (PLRV; Genus Polerovirus; Family Luteoviridae). Pages 69-75 in: Virus and Virus-like Diseases of Potatoes and Production of Seed Potatoes. G. Loenbenstein, P. H. Berger, A. A. Brunt, and R. H. Lawson, eds. Kluwer Academic Publishers, The Netherlands.

39. Loebenstein, G. 2001. Potato virus $X$ (PVX; Genus Potexvirus). Pages 87-94 in: Virus and Virus-like Diseases of Potatoes and Production of Seed Potatoes. G. Loenbenstein, P. H. Berger, A. A. Brunt, and R. H. Lawson, eds. Kluwer Academic Publishers, The Netherlands.

40. Loenbenstein G., Berger P. H., Brunt, A. A. and Lawson R. H., eds. 2001. Virus and viruslike diseases of potatoes and production of seed potatoes. Kluwer Academic Publishers,
The Netherlands.

41. Manuchehri-Kashani, A. 1968. Virus Diseases of Plants. Tehran University Press, Tehran, Iran.

42. Martelli, G. P., and Russo, M. 1973. Eggplant mottled dwarf virus. AAB Descriptions of Plant Viruses, No. 115.

43. NIVAA. 1997. Netherlands catalogue of potato varieties. NIVAA, Den Haag, The Netherlands.

44. Peters, D. 1970. Potato leafroll virus. AAB Descriptions of Plant Viruses, No. 36.

45. Pourrahim, R., Ahoonmanesh, A., Farzadfar, S., and Khakvar, R. 2000. Identification of a strain of Alfalfa mosaic virus as the causal agent of potato tuber necrosis. Page 314 in: Proc. Plant Prot. Congr. Iran, 14th.

46. Pourrahim, R., Farzadfar, S., Moinin, A. A., Shahraeen, N., and Ahoonmanesh, A. 2001. First report of Tomato spotted wilt virus (TSWV) on potatoes in Iran. Plant Dis. 85:442.

47. Pourrahim, R., Shahraeen, N., Ahoonmanesh, A., and Karimi, A. R. 1998. Report on occurrence of necrotic strain of Potato virus Y $\left(\mathrm{PVY}^{\mathrm{n}}\right)$ on potato in Hamedan province. Iran. J. Plant Pathol. 34:37.

48. Robert, Y., and Bourdin, D. 2001. Transmis- sion of viruses. Pages 195-225 in: Virus and Virus-like Diseases of Potatoes and Production of Seed Potatoes. G. Loenbenstein, P. H. Berger, A. A. Brunt, and R. H. Lawson, eds. Kluwer Academic Publishers, The Netherlands.

49. Salazar, L. F. 1996. Potato viruses and their control. Intern. Potato Center, Lima, Peru.

50. Thomas, P. E. 1979. Beet curly top virus. AAB Descriptions of Plant Viruses, No. 210.

51. Thresh, J. M. 1976. Gradiants of plant virus diseases. Ann. Appl. Biol. 82:381-406

52. Wetter, C. 1971. Potato virus S. AAB Descriptions of Plant Viruses, No. 60.

53. Wetter, C. 1972. Potato virus M. AAB Descriptions of Plant Viruses, No. 87

54. Winter, S., Koerbler, M., Shahraeen, N., Katul, L., and Lesemann, D. E. 2002. Characterization of a new Tospovirus species infecting tomato in Iran. Page 120 in: Proc. 1st Joint Conf. Int. Working Group Legumes Vegetable Viruses. Bonn, Germany.

55. Winter, S., Shahraeen, N., Koerbler, M., and Lesemann, D. E. 2006. Characterisation of Tomato fruit yellow ring virus: A new Tospovirus species infecting tomato in Iran. Plant Pathol. 55:287. 